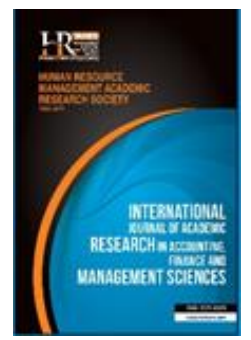

International Journal of Academic Research in Accounting, Finance and Management Sciences

Vol. 8, No.1, January 2018, pp. 153-160

E-ISSN: 2225-8329, P-ISSN: 2308-0337

(C) 2018 HRMARS

www.hrmars.com

To cite this article: Popescu, A.M. (2018). The Main Theoretical Aspects Regarding Bank Risks. Models For Their Management, International Journal of Academic Research in Accounting, Finance and Management Sciences, 8 (1): 153-160.

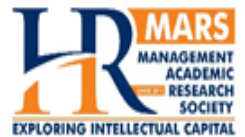

http://dx.doi.org/10.6007/IJARAFMS/v8-i1/4040 (DOI: 10.6007/IJARAFMS/v8-i1/4040)

\title{
The Main Theoretical Aspects Regarding Bank Risks: Models for their Management
}

\author{
Ana Maria POPESCU \\ Bucharest University of Economic Studies, Romania, E-mail: contact.ana@gmail.com
}

\begin{abstract}
Banking activity involves a number of risks due to unforeseen events, possibly occurring. From this point of view the risks can not be avoided, because in the socio-economic evolution appear a series of elements, a series of aspects that are difficult to predict. Banking activity should be prudential, in the sense that, with increased attention, some elements that may lead to the emergence of risk can be identified in time. Risks can be random and uncontrollable, such as natural hazards that can hardly be identified. But there are management risks that can be identified, can be quantified, and measures can be taken in this context to ensure that they are diminished if not eliminated. Banking operations and procedures by an even specialized staff are ultimately an element that may also include germs of risk. Banking risks need to be managed, ie they need to be known and steps taken to minimize, at least probabilistically, their. Of course, for a bank it is necessary that its products lead to higher incomes than the expenses incurred. The bank benefit results from a volume of operations and a rate of benefit, but these can not be achieved each time. Banking should be subject to compliance with current banking regulations, but at the same time there may be a series of deviations that turn into risks that impact on banks' financial results. There are several risk categories depending on the exposure to risk, the characteristics of each bank, the duration or the coverage of these risk effects in the balance sheet. As a rule, banking risks, if propagated, lead to unwanted results, lead to a decrease in the ability to meet profitability indicators.

Key words Banking risk, management, financial-banking analysis, provision, banking product

Received: 28 Dec 2017 (C) The Authors 2018

Revised: 08 Feb 2018 Published by Human Resource Management Academic Research Society (www.hrmars.com)

Accepted: 18 Mar 2018 This article is published under the Creative Commons Attribution (CC BY 4.0) license. Anyone may reproduce, distribute, translate and create derivative works of this article (for both commercial and non-commercial purposes), subject to full attribution to the original publication and authors. The full terms of this license may be seen at: http://creativecommons.org/licences/by/4.0/legalcode
\end{abstract}

\section{Introduction}

In the study presented in this article, initial the author focused on identifying the conditions for the emergence of banking risks and continued with the study of how to manage these bank risks. Banking risk management is broadly presented in the sense that there needs to be a strong correlation in an appropriate framework where concrete measures for identifying, measuring and eliminating or mitigating risks are foreseen. Of course, the goal of each bank is to be as profitable as possible, but banking activity takes place in a particular environment, subject to particular risks. Thus, there are liquidity risks, due to the impossibility of obtaining some provisioned incomes or non-performing loans. There is also interest rate risk in the sense that interest is not always well established and well established or credit risks because any credit presents a risk to both the bidder and the beneficiary legal or physical entity. Next, we focused on studying and presenting the objectives of financial management, the presentation of some indicators on which risk is identified and calculated. In the article we also referred to the exposure to risks, which is regarded as an inherent exposure and as an additional or subjective exposure. The pure risks refer to the 
fact that the exposure is generated by purely banking activities that, in a faulty management, may have negative outcomes that affect the activity of the banking corporation. Risks may be physical, financial, criminal, fraudulent or liability risks. All these risks are presented as important for the management plan of the banking company.

\section{Literature review}

Aebi et al. (2012) investigated the extent to which corporate governance mechanisms related to risk management are associated with better performance of the bank during the 2007-2008 financial crisis. Agoraki et al. (2011) investigated whether regulations in the field generate an independent effect on banks' risk or whether their effect is channeled through the market power held by banks. Anghel (2015) analyzed the main risks faced by banks and their methods and models of management. Anghelache et al. (2017) studied the interest rate risk with regard to the modalities, the quantification and the measures taken to reduce, as much as possible, the cancellation, in order to limit the vulnerabilities in the banking activity. Anghelache et al. (2017) analyzed various aspects of information asymmetry, various private scenarios, and attempted to construct simple models illustrating the essence and involvement of information asymmetry in decision-making. Beltratti and Stulz (2012) investigated the reasons why some credit institutions had better performance in the global credit crisis. Blundell-Wignall and Atkinson (2010) analyzed how Basel III proposals can help reduce the chances of a new financial crisis. Bushman and Williams (2012) have shown that early provisioning, designed to ease earnings, mitigates risk-taking discipline, in line with the diminishing transparency that hinders external monitoring. Cope (2012) presented a method for integrating loss data used in operational risk quantification with scenario analysis. Delis and Kouretas (2011) demonstrated that the low interest rate substantially increases the risk of banks. Hakens and Schnabel (2010) addressed a number of issues related to credit risk transfer and banking competition. HernándezCánovas and Martínez-Solano (2010) studied the correlation between the loan system and small and medium-sized enterprises in the continental-European banking system. Ippolito, Peydrób, Poloc and Sette (2016) presented a number of elements regarding the management of liquidity risk. Jiménez, Lopez and Saurina (2013) tried to identify how competition is affecting bank risk. McPhilemy (2014) studied the integration of regulation and prudential banking supervision in the European Union. Mirzaei, Moore and Liu (2013) investigated the effects of market activity, banking activities and the banking environment on profitability and stability for a number of banks in emerging and advanced economies. Peters et al. (2009) have modeled dependence on operational risks.

\section{Research methodology and data. Results and discussions}

Banking activity, irrespective of the strategy used, is exposed to various risks specific to this activity.

The legal framework regulates 'exposure' as a commitment by a bank towards a debtor, whether actual or potential, as evidenced in the balance sheet or off-balance sheet, including, as a rule, credits, expected trading effects, equity investments and other values securities, traded effects, issued guarantees, open and / or confirmed letters of credit.

In order to establish a prudential banking framework, the right of the National Bank of Romania to be the only supervisory and control authority that can issue operating authorization and requires the opening of accounts by any bank to the NBR, the establishment of minimum reserve funds from the profit gross of up to $20 \%$ until the fund is equal to the share capital, and then maximum $10 \%$ until the fund has doubled the subscribed and paid-up share capital.

Banking risk focuses on the classical function of banks, of intermediation in the sphere of financial risks. Thus, we may consider unexpected losses from bank assets, losses caused by market, credit or liquidity risks, losses caused by entirely random and uncontrollable risks (fraud, fire or natural disaster).

In practice, risks arise from management techniques that can be improved. By improving the banking management models and techniques, it is ensured that banking risks are known and diminished.

Banking risk is generated by operations and procedures that should be considered as a complex system of interdependent risks as they may have common causes or that the production of one may generate other risks in the chain. Consequently, these operations and procedures generate constant exposure to risk. 
Given that banks are also active in other markets, both for their own benefit and for the economic and financial activity of the agents they serve, there is also the exchange risk that needs to be managed correctly. Foreign currency-denominated transactions are also subject to currency-currency arbitrage transactions.

Banking risk management programs and procedures are in place to identify, quantify and establish a robust banking strategy to reduce the likelihood of such risks and exposure to the bank. Banking policies aim at minimizing losses (additional costs borne by the bank), and the central focus of banking activity is to obtain an additional, guaranteed profit.

The general and sectoral objectives are, as a rule, not consistent. Sometimes the cost of implementing and using risk management procedures is wrongly dimensioned against actual exposure to risk. Therefore, these programs should be set according to efficiency criteria. The objectives of banking management are to maximize profitability, minimize risk exposure and comply with banking regulations.

Banking products (interest on loans granted) need to exceed bank charges (interest paid for collected resources) and that the balance thus collected, called net banking product (PBN), is higher than the operating expenses. From a statistical point of view, the analysis indicators can be expressed through the following relationships:

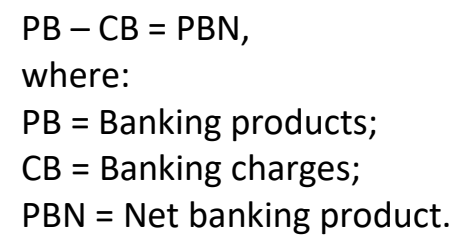

and

$\mathrm{PBN}-\mathrm{CE}=\mathrm{PNF}$,

where:

$\mathrm{PBN}=$ Net banking product;

$\mathrm{CE}=$ Operating Expenses;

$\mathrm{PNF}=$ Final net profit.

It follows that the profitability of banks is achieved by increasing the net banking product and reducing operating costs. The net banking product results from the volume of operations and the benefit ratio. The volume of operations is determined at the macroeconomic level, the monetary mass, and at the microeconomic level, the size of the bank and its own established strategy.

The benefit rate is based on the type of activity of the bank. For example, medium to long-term credit banks are funded. mainly on the money market and have low operating costs.

Banks take advantage of the rise in benchmark interest, as all loans follow this trend, while some of the resources remain at fixed interest (savings accounts) or null (ordinary deposit accounts). PBN is determined in particular by the difference between money market interest (which accounts for the bulk of the cost of its own resources) and bank base interest.

Operating expenses consist of wage costs, general expenses and commissions, being influenced by the degree of banking, personnel policy, etc. Minimizing exposure to risk can be achieved through good customer knowledge (minimizing the risk of insolvency) and a good estimate of overall economic performance. Insolvency is the main risk and is covered by the volume of collateral. Banks have more confidence in the effectiveness of real (mortgage) or personal (bail) guarantees than in the debtor's economic analysis.

In order to hedge against interest risks, banks are correlating long-term resources for long-term uses. A bank can take short-term loans and lend in the long run or vice versa.

The exchange rate may cause significant losses, banks being engaged in foreign exchange operations, being able to insure against this risk by using identical conditions and having as many debt claims as possible. In this case, the change in the exchange rate does not affect the outcome. 
The financial structure is correlated with interest and exchange rate risks, which it assumes. Liquidity risk occurs if depositors ask to withdraw their funds. Thus a lot of banks in Romania went bankrupt during the period of primary evolution and the consolidation of the banking market.

The third objective of banking management (compliance with the banking regulations in force) is mandatory for each bank.

Regulatory restrictions emanate from the guardianship authority (NBR), which provides depositary security and government monetary policy.

The security of deposits is based on three liquidity, hedging, and risk-spreading ratios.

The liquidity ratio consists in the need for a credit ratio of less than three months/deposits under three months to be greater than or equal to $60 \%$. In other words, short-term resources should not be used more than $40 \%$ to complete long-term use.

The risk coverage ratio is intended to limit banks' insolvency risk. Own funds (capital + reserves) should represent $5 \%$ of the bank's risks.

The risk-sharing factor limits the amount of credit that a bank can give to the same client, thus limiting it in the event of bankruptcy of a client.

The implementation of the government's monetary policy targets objectives such as the defense of the national currency (maintaining the exchange rate) and the fight against inflation. The classic solution consists of an interest-bearing action. The action of the tutelage authorities on interest is exercised either through refinancing procedures (main interest) or by manipulating money market interest. Other interest and, in particular, the banking base remain, ".

Under the conditions of an adequate management, the growth of operations in the two large areas, traditional services and new services should have a synergistic effect.

Because bank risks are a source of unforeseen expenses, their proper management can stabilize revenue over time. Strengthening the value of bank shares can only be achieved through real-world communication with financial markets and the implementation of bank risk management programs. Banking risk management and the global management system ensure the stability and financial efficiency of the bank.

Banking risks are grouped into classes and types of risk, and their correlated treatment allows observations that can facilitate understanding of the management process and assimilation of appropriate procedures and techniques.

The risk exposure of a financial institution, although generated by the same set of activities, can be regarded as inherent exposure and additional (subjective) exposure.

The pure risks are characterized by the fact that the exposure is generated by the banking activities and processes that can lead to losses.

Pure risks can be divided into: physical risks: damage and destruction of buildings, damage to buildings under construction, destruction of telecommunication lines, damage to machines and miscellaneous materials, damage to material during transport, traffic accidents, etc .; financial risks: complete data loss, loss of collected cash, destruction of archives, loss of effects, etc.: criminal and fraudulent risks: infiltration into computer files, fraudulent use of means of payment, theft, armed attack, misappropriation of funds to an employee etc.

The demarcation of the speculative and pure risks is not net. as can be seen from the following table. In the table, the types of risk are exemplified by several categories of bank risks.

Table 1. Classification of types of risks

\begin{tabular}{|c|c|c|c|c|c|}
\hline \multirow{2}{*}{ Types of risks } & \multicolumn{3}{|c|}{ Speculative (loss/gain) } & \multicolumn{2}{|c|}{ Pure (loss only) } \\
\hline & Market & Business & Liquidity & Performance & Event \\
\hline $\begin{array}{l}\text { Category of } \\
\text { risks }\end{array}$ & $\begin{array}{ll}- & \text { securities; } \\
\text { - } & \text { goods; } \\
\text { - } & \text { currencies. }\end{array}$ & $\begin{array}{ll}- & \text { strategies; } \\
- & \text { personal organization; } \\
- & \text { technology; } \\
\text { - } & \text { image and marketing. }\end{array}$ & $\begin{array}{l}\text { - markets; } \\
\text { - companies. }\end{array}$ & $\begin{array}{l}\text { - counterparty; } \\
\text { - insurance. }\end{array}$ & $\begin{array}{l}\text { - assets and } \\
\text { damage; } \\
\text { - life and health. }\end{array}$ \\
\hline
\end{tabular}




\begin{tabular}{|l|l|l|l|l|l|}
\hline Main causes & - changes in the & - managerial appreciation; & - capacity & - employee errors & - sickness of \\
demand-offer & - limited information & employees; \\
report; & - the actions of competition; & - system & or theft; \\
- anticipated & - changing consumer needs. & - leadership & failure; \\
market & - natural disasters; \\
conditions. & & actions - business \\
information. & failure. & & -accidents. \\
\hline
\end{tabular}

Financial risks can be considered the most important group of banking risks, as their bad management even produces bank failures. In this group of risks we consider: credit risk, also called debtor insolvency risk, default risk or risk of deterioration in the quality of bank assets; the liquidity risk or the financing risk expresses the likelihood of effective financing of banking operations; market risk that appears as a risk of interest rate variation that negatively affects bank profits; bankruptcy risk (risk capital or leverage risk) shows the probability that the bank's own funds are insufficient to cover losses from current activity.

There is a constant interaction between risk groups because it only expresses different aspects of the same risk potential arising from current banking operations.

Performance risks associated with operations in the field of financial services and these are: operational risk or risk of pregnancy the probability that the bank becomes incapable of ensuring customer service in a cost effective manner; the technological risk is associated with the quality and structure of the supply of financial products that also have their own lifecycle and tend to be replaced by more productive products. the new product risk associated with financial product innovation; strategic risk expresses the probability of not choosing the optimal strategy under the given circumstances.

The environmental risk group comprises a class of risks with a strong potential for impact on bank performance. In this class we find: the risk of fraud (is a risk of internal and expresses, in fact, the probability of committing theft or some other acts against the interests of the bank by its employees; frauds affect sensitive profitability of the bank, when they can not 11 detected early and recovered); the economic risk associated with the evolution of the economic environment in which the bank and its clients act; the competitive risk expresses the likelihood of profit reduction under the conditions of changing market relationships to the detriment of the bank; the legal risk that reflects the fact that banks have to operate in the context established by the regulations in force, even if they create a competitive disadvantage to other competing financial institutions.

The following table presents the classification of the main types of risks.

Table 2. Classification of banking risks by cause and form

\begin{tabular}{|l|l|l|}
\hline \multicolumn{1}{|c|}{ Banking feature } & \multicolumn{1}{|c|}{ Risk group } & \multicolumn{1}{c|}{ The type of risk } \\
\hline Balancing operations & Financial & Credit risk \\
& & Liquidity risk \\
& & Market risk \\
& & Risk of bankruptcy \\
\hline Banking services & of performance & Operational risk \\
& & Technological risk \\
& & Risk of new products \\
& & Strategic risk \\
\hline Framework of activity & Ambiental & Risk of fraud \\
& & Economic risk \\
& & Competitive risk \\
& & Legal risk \\
\hline
\end{tabular}

Risks can be considered to be diversifying or non-diversifying.

Diversible risks are those that become insignificant when combined with other positions (balancing), according to the statistical law of large numbers. 
Non-diversified risks remain relatively significant as exposure, even after all possibilities to use the law of large numbers have been explored. For example, the risk of default on a loan contracted by a client is non-diversifying. The more borrowers the bank has, and the lower the amount of loans granted to each bank relative to the bank's capital, the less likely will be that the default of one of these loans will cause the bank serious liquidity or capital problems.

Non-diversified risks are determined by interest rates; currency exchange rates; raw material prices; macroeconomic indicators.

These variables are endogenous because they reflect variations in consumer preferences, technology changes, government policies.

From the point of view of risk management, their exact source is, however, less important than the transmission channel, which is the price, and specific protection can be conceived only in the case of divergent risks.

By defining the risk as the probability of producing an uncertain event for which the distribution of the effects of its production is known, or for which it can be approximated by the study of the random effects already produced, then the uncertainty is associated with events for which the distribution of effects is completely unknown.

In the case of risks, protection is ensured through the management and use of specific techniques and instruments and through capital. In order to protect the bank in the case of non-diversified risks and pure uncertainty, nothing can replace banking capital and no technique or tool, however sophisticated, can provide sufficient protection. The bank's risk and performance effects are reflected in the annual balance sheet. Balance sheet, in addition to off-balance sheet accounts, and the following annexes: treasury and interbank sector; customers; operations with securities; term assets: fixed assets and permanent liabilities in liabilities. The weights of the four levels vary from one bank to another, and the risks differ from those on the market or off balance sheet.

Commercial banks apply classical management methods based on balance sheet and balance sheet "customer" and "interbank". The two parts of the balance sheet are not balanced, depending on the ability to collect resources or lending policy. Active-passive management consists in defining the funding policy so that global risks respect the objectives and limits chosen.

Market activities are not subject to the management of brokering activities. Market operations are subject to market and credit risk. Partners in market activities are financial institutions.

Off-balance sheet commitments include those that are unrelated to the cash flow. It may be commitments offered or accepted in favor of credit or customer institutions, ie contractual commitments to be honored (confirmed credit lines, offered or required guarantees, bail).

Medium-quality loans include those in sight, plus standard or doubtful loans. For the portfolio of liabilities a similar indicator is calculated according to the ratings of the portfolio titles.

This indicator results from the ratio of portfolio losses and the total value of the loan portfolio. The value of this report should be as small as possible and shows that the portfolio has been managed efficiently in terms of credit risk. This size also serves to establish the reserves on the loan portfolio from which these losses are covered. The calculation relation is as follows:

$$
I_{p p}=\frac{P_{t p}}{V_{t p}} \times 100
$$

Where:

$I_{p p}=$ portfolio loss index;

$\mathrm{P}_{\mathrm{tp}}=$ total loss in portfolio;

$\mathrm{V}_{\mathrm{tp}}=$ the total value of the portfolio.

Analogously, the value of the loss ratio on the debt securities portfolio can be calculated based on the total value of the portfolio of debt securities, namely:

$$
R_{p p}=\frac{P_{\text {tcr }}}{V_{\text {ttc }}}=100
$$

where: 
$\mathrm{R}_{\mathrm{pp}}=$ loss ratio for debt securities;

$P_{\text {tcr }}=$ loss on loan securities;

$\mathrm{V}_{\mathrm{ttc}}=$ total value of the loan portfolio.

Dynamics of the reserve fund to cover losses on the loan portfolio expresses how the bank's management expressed the evolution of the exposure to credit risk:

$I_{\mathrm{FR}}=\frac{R_{\mathrm{pc}}}{\mathrm{V}_{\mathrm{t}}} \times 100$

Where:

$\mathrm{I}_{\mathrm{FR}}=$ reserve fund dynamics;

$\mathrm{R}_{\mathrm{pc}}=$ losses from the loan portfolio;

$V_{t}=$ total value of the bank's activity.

The higher the planned reserves for which provision is made. the more likely it is that the bank is considering higher losses. If two parameters grow at the same pace, there can be no increase in risk exposure. Depending on the regulations in force, the bank may adopt a different policy for setting up the reserve fund for losses. The indicator is used throughout the banking system as an alarm signal.

Dynamics of assets and. especially of total loans, are interpreted as indicators of banking risk when expressing an accelerated growth. This is because, based on experience, it is assumed that each banking institution has a limited capacity to properly manage the loan portfolio for a given volume.

Relative ratios of banking assets to equity and bank funds are used as they give a quantitative expression of the relationship between exposure to risk and the source of funding. Indicators are used, such as:

- the net profit attributable to losses on the credit portfolio is calculated from:

$\mathrm{I}_{\mathrm{pn} / \mathrm{ppc}}=\frac{\mathrm{P}_{\mathrm{n}}}{\mathrm{P}_{\mathrm{pc}}} \times 100$

where:

$I_{\mathrm{pn} / \mathrm{ppc}}=$ loss indicator of net profit on account of losses on the loan portfolio;

$\mathrm{P}_{\mathrm{n}}=$ net profit;

$\mathrm{P}_{\mathrm{pc}}=$ losses from the loan portfolio.

Net profit is the main source of loss financing. The indicator is sometimes superunit and is therefore reversible, that is, it can also be calculated in reverse, but then it is subunit. It is important that the bears are covered.

- the ratio between the reserve fund and the losses on the loan portfolio is calculated from:

$\mathrm{I}_{\mathrm{FR} / \mathrm{ppc}}=\frac{\mathrm{FR}}{\mathrm{P}_{\mathrm{pc}}} \times 100$

Where:

$\mathrm{I}_{\mathrm{FR} / \mathrm{ppc}}=$ index of the ratio between the reserve fund and the losses in the loan portfolio;

$\mathrm{FR}=$ reserve fund;

$P_{p c}=$ losses from the loan portfolio.

This ratio must be greater than 1 in order to be able to appreciate that management is prudent.

The value of this indicator allows us to appreciate the quality of the loan portfolio and its evolution. For internal use, these indicators can be calculated and therefore can be interpreted in a correlated way, analyzed, and used in substantiating credit policy.

\section{Conclusions}

From the study underlying this article it follows that, since bank risks are a source of extra unexpected expenditure, their management can stabilize revenue over time, meaning that the measures 
taken can be regarded as a buffer for negative effects. Another conclusion is that in the management and management of banking risks, the financial market must be taken into account, and its implementation should be closely aligned with the legislative framework, with the Basel I, II and III agreements so as to avoid the emergence and the manifestation of the effects of the risks. If bank management foresees concrete measures in relation to risk management, we can assume that the bank is aware of, it has measures to be taken and in case of occurrence of the conditions that determine the occurrence of the risks it can avoid. In this way, the bank, by avoiding the risks, regardless of their nature, manages to harmonize a profitable activity. Poor management of some banks, and especially imperfections in providing risk identification, measurement and elimination measures, lead to negative influences, and most often, as happened in the period up to 2000, banks are gradually going into insolvency and then in declaring bankruptcy. That is why knowledge of risks and their identification, their management and their correct management are important in the activity of any banking company.

\section{References}

1. Aebi, V., Sabato, G. and Schmid, M. (2012). Risk management, corporate governance, and bank performance in the financial crisis. Journal of Banking and Finance, 36, 3213-3226.

2. Agoraki, M.E., Delis, M.D. and Pasiouras, F. (2011). Regulations, competition and bank risk-taking in transition countries, Journal of Financial Stability, 7, 38-48.

3. Anghel, M.G. (2015). Analiză financiar-monetară, Editura Economică, Bucureşti.

4. Anghelache, C., Bodo, G., Sfetcu, M. and Mirea, M. (2017). Model for Analyzing the Sensitivity of the Bank's Risk Indicators to the Interest Rate Variation. Romanian Statistical Review, Supplement, 12, 64 75.

5. Anghelache, C., Bodo, G. and Marinescu, A.I. (2017). Asymmetric information in case of decision under risk. Romanian Statistical Review, Supplement, 1, 22-36.

6. Beltratti, A. and Stulz, R. (2012). The credit crisis around the globe: Why did some banks perform better?. Journal of Financial Economics, 105, 1-17.

7. Blundell-Wignall, A. and Atkinson, P. (2010). Thinking beyond Basel III. Necessary Solutions for Capital and Liquidity. OECD Journal: Financial Market Trends, 2 (1), 9-33.

8. Bushman, R. and Williams, C. (2012). Accounting discretion, loan loss provisioning, and discipline of Banks' risk-taking. Journal of Accounting and Economics, 54 (1), 1-18.

9. Cope, E. (2012). Combining scenario analysis with loss data in operational risk quantification. The Journal of Operational Risk, 7 (1), 39-56.

10. Delis, M. and Kouretas, G. (2011). Interest rates and bank risk-taking. Journal of Banking \& Finance, 35 (4), 840-855.

11. Hakens, H. and Schnabel, I. (2010). Credit Risk Transfer and Bank Competition. Journal of Financial Intermediation, 19 (3), 308-332.

12. Hernández-Cánovas, G. and Martínez-Solano, P. (2010). Relationship lending and SME financing in the continental European bank-based system. Small Business Economics, 34 (4), 465-482.

13. Ippolito, F., Peydrób, J.L., Poloc, A. and Sette, E. (2016). Double bank runs and liquidity risk management. Journal of Financial Economics, 122 (1), 135-154.

14. Jiménez, G., Lopez, J. and Saurina, J. (2013). How does competition affect bank risk-taking?. Journal of Financial Stability, 9 (2), 185-195.

15. McPhilemy, S. (2014). Integrating rules, disintegrating markets: the end of national discretion in European banking?. Journal of European Public Policy, 21 (10), 1473-1490.

16. Mirzaei, A., Moore, T. and Liu, G. (2013). Does market structure matter on banks' profitability and stability? Emerging vs. advanced economies. Journal of Banking \& Finance, 37 (8), 2920-2937.

17. Peters, G.W., Shevchenko, P.V. and Wüthrich, M. (2009). Dynamic Operational Risk: Modeling Dependence and Combining Different Sources of Information. The Journal of Operational Risk, 4 (2), 69104. 